\title{
Cardiovascular System Findings Data Collection Date Time
}

National Cancer Institute

\section{Source}

National Cancer Institute. Cardiovascular System Findings Data Collection Date Time.

NCI Thesaurus. Code C123946.

The date and time of cardiovasulcar system data collection. 